\title{
Drawing Futures
}

Over the last half century, numerous philosophers and theorists - prompted by Wittgenstein and Heidegger - have challenged the assumption that language is a neutral instrument. For them and their followers, we are not in charge of language. Rather, the structures and connotations of language determine our possibilities for expression. Architectural drawing and modelling are often considered neutral instruments: means of straightforward communication between architect and client, engineer and project manager, contractor and sub-contractor. The conventions of drawing, which are even prescribed authoritatively by European standards, are ingrained so deep in the architectural mind that they are rarely given much attention. Yet drawing, too, is no neutral instrument. The right angle was a cause célèbre in architectural modernism, but it was also a practical expedience in an age of T-squares and set squares. And there is the story - is it apocryphal? about a prevalence of double-curved steel roofs in the UK after that option was offered by a new release of AutocAD software in the 199os. Just as language conditions possibilities for expression in words, so drawing and modelling would seem to condition possibilities for expression in architecture.

In this vein, historians have found the discovery of perspective and its subsequent influence to be decisive in the conception of architecture. Alberto Pérez-Gómez explores here historical shifts in the relations of drawing and architecture in order to challenge what he sees as the prevalent notion that a conventional set of projections, at various scales from site to detail, add up to a complete objective idea of a building (pp 217-225). Likewise, Paul Emmons addresses the notion of scale - understood as the imaginative inhabitation of a drawing - considering the lessons of its historical development for contemporary architects (pp 227-235).

Both Pérez-Gómez and Emmons see in the influences of CAD the beginnings of a shift in conceptions of architecture as fundamental as that instigated by perspective. Yet it is rare for the developers of computer visualisation techniques to consider their work in a historical context. An exception is Mathan Ratinam, whose paper (pp 237-244) explores a new means of representing architecture that combines historical techniques of quadratura with photogrammetry.

Several papers in this issue stem from an academic conference, hosted by AHRA (the Architectural Humanities Research Association) and the Institute of Architecture at the University of Nottingham, on the topic of 'Models and Drawings' (see report on pp 185-187). More than a matter of arcane academic interest, it seems that there is much to be gained for practitioners from an increasing awareness of the ways in which drawing can mediate between thinking and making. One such architect is Christopher Platt who describes his work through Studio KAP with particular reference to the role of working drawings in the practice (pp. 198-215). With rapid developments in CAD techniques, especially in relation to Computer Aided Making (as explored by Bob Sheil in arq 9/1, pp. 20-32), it is highly likely that the loaded mediations of drawing and modelling will be a topic to which arq returns in future. Submissions in this area from practitioners and academics alike will be received with interest. 


\section{architectural research quarterly}

\section{Subscribe now for 2006}

Innovative in conception, unique in breadth

and generously illustrated, this pace-setting

quarterly publication from Cambridge

University Press links, on a global scale,

the worlds of architectural practice and

research. arq regularly includes extensive

peer-reviewed sections on design, history,

theory, construction, environmental design,

information technology and practice - as

well as structures, urbanism and documents.

These are supplemented by letters, reports,

reviews, a directory of specialist research

centers and consultancies and an annual

index. Each issue opens with a leader and

closes with insight, a personal end-piece. In

its three year history, arq has published work

from all over the world: from Chile to Sweden

and from Japan to the Netherlands - with a

strong representation from the United Kingdom

and United States. arq, like architecture itself,

is all-embracing and written by and for both

practitioners and academics. It provides an outlet

for all those who wish to disseminate

their work to an international audience.
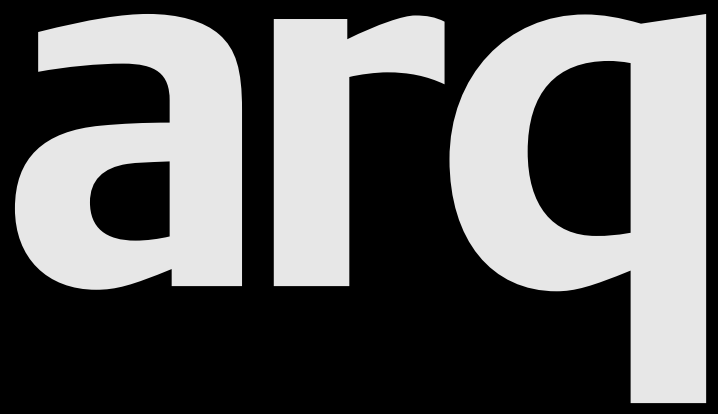

Please enter my subscription to

arq: architectural research quarterly, volume 9, 2005

$\square$ E145/\$233 institutions print and electronic

$E_{30} / \$ 50$ students print only

£42/\$64 individuals print only

EU residents only. VAT may be payable at your local rate if not registered.

Our VAT registration number: GB 214141614

If registered, your VAT registration no:

Total subscription payment $€ / \$$

EU residents only, if not registered add VAT at appropriate rate ${ }^{£}$

Canadian residents, add 7\% GST \$

Total $\mathbf{E} / \$$

Name

Address

Payment enclosed

Cheque in sterling or US dollars

(payable to Cambridge University Press)

Credit Card - VISA | MasterCard | American Express (delete where applicable)

Card no

Expiry date

Signature

Photocopy this page and send your order to:

Journals Customer Services, Cambridge University

Press, The Edinburgh Building, Cambridge, CB2 2RU,

UK

$T+44(0) 1223326070$

F +44 (o) 1223315052

E journals@cambridge.org

or in USA, Canada and Mexico send to:

Cambridge University Press, 40 West 2oth Street,

New York NY 10011-4211, USA

T (914) 9379600

F (914) 9374712

E journals_subscriptions@cup.org 